\title{
Alternative Mechanism to Deal with Stressful Condition: Do We Really have a Social Support?
}

\author{
Sugiarti Agus Musabiq \\ Faculty of Psychology, University of Indonesia \\ sugiartipsi@gmail.com
}

\author{
Siska Aris Nur Fitri \\ Faculty of Psychology, University of Indonesia \\ siskaaris7@gmail.com
}

\begin{abstract}
This study aims to determine the role of health promoting behavior as a mediator of the relationship between perceived social support and psychological distress in poor young adults in DKI Jakarta. The research data collection was directly conducted by visiting the participants, young adults with age 8-29 years old $(N=3 \mid 4)$. The research instruments used were HPLP II, Social Provision Scale (SPS), Symptom-25 Checklist (HSCL-25). The results of the mediation analysis showed the significancy that health promotion behavior partially mediated the relationship between perceived social support and psychological distress, with indirect effects $(\beta=.003, p=<.0 \mathrm{I})$ and direct effects $(\beta=-.022, p=<.01)$. Thus, perceived social support can directly increase psychological distress or through health promotion behavior first. People who perceive themselves get social support will have feeling that are cared for and loved, so that they will motivate themselves to be involved in healthy behavior and reduce psychological distress.
\end{abstract}

Keywords: Health-promoting behavior, perceived social support, poor young adults, and psychological distress.

\section{Introduction}

In Indonesia poverty is often associated with low economic status. According to the Central Statistical Agency (2018) poverty is defined as the inability of individuals in terms of economic aspects to meet basic needs, such as food and non-food measured by financial expenditure. Poverty which is indicated by low socio-economic status can cause stress (Mirowsky \& Ross, 2003). According to Hanadita and Tampubolon (2016) poverty in Indonesia can also be assessed from the health and education level of the Indonesian people. Thus, health and education factors are important to get further attention, especially related to poverty. The aim of this study was to determine the role of health-promoting 
behavior as a mediator of the relationship between perceptions of social support and psychological distress.

Problems often occur in densely populated areas. Jakarta is the most crowded city in Indonesia. Every year there are always migrants in Jakarta. According to the Central Statistics Agency (2017) the population density in DKI Jakarta reached I5,663 people / $\mathrm{km}^{2}$, this number increased by $0.93 \%$ from the previous amount of 15,518 people $/ \mathrm{km}^{2}$. This increasingly makes Jakarta densely populated with competition in various fields of life that are getting tougher, such as finding jobs, increasing needs and various social facilities, crime, and others. The results of survey by zipjet.co.uk (2017) state that DKI Jakarta has an index of 7.84 from 10.00 which means it ranks 18th out of I50 cities with the highest stress levels in the world.

Population of urban life has the effect of stress experienced by its people (Mubi \& Pavoni, 2017). Mirowsky and Ross (2003) add that stress experienced by individuals can influence socio-economic status. Communities with low economic status are more vulnerable to stress. High levels of stress in Jakarta is as a result of mental or physical health in the community (zipjet.co.uk, 2017). Based on the results of the 2013 Basic Health Research, the prevalence of mental emotional disorders was more experienced by urban communities than in urban communities (Ministry of Health, 20I3). The mental emotional disorders included depression and anxiety included in psychological distress (Mirowsky \& Ross, 2003). Psychological Distress is an unpleasant condition experienced by individuals including depression and anxiety. Drapeau, Marchand, \& Beaulieu-Prevost (2012) explain that psychological distress is increasingly experienced by individuals in populations with high levels of distress risk, one of which is low socioeconomic status. The results of Feldman and Steptoe's (2004) study confirm that a low socioeconomic level is significantly positively correlated with environmental tensions and results in worse physical functioning of individuals.

According to Bonnie, Stroud, and Breiner (2015) the development period of young adults aged 18 years to 25 years has proven to be most susceptible to psychological distress, the results of research by Kessler, Chiu, Demler, and Walters (2005) describe young adults up to 29 years of age most vulnerable psychological problems. Based on the results of these studies, this study will focus on poor young adults aged 18 to 29 years in DKI Jakarta. Psychological distress is one of the important mental health problems to get further attention, but on the other hand along with the increase of individuals who experience psychological problems have not been balanced with access to adequate mental 
health services, so it is important to know the factors that can reduce psychological problems, especially psychological distress to design an appropriate and effective intervention program.

Matthews (2007) stated that psychological distress has three effects: decreased performance, cognitive bias, and clinical impairment. One form of performance decline is that individuals become slow and inaccurate when carrying out various tasks. Anxiety makes it difficult for the individual to focus on work. In addition, individual self-control and working memory function are also impaired. For cognitive bias, psychological distress usually impairs cognitive functions such as selective attention and a tendency to remember negative events. Finally, psychological distress is the main symptom of mood and anxiety disorders that are clinical in nature which often lasts a long time.

One factor that can reduce psychological distress is the perception of social support. Perception of social support is one of the inhibiting factors for the emergence of psychological distress, even able to protect individuals from problems of mental health disorders with a high effect size (Cobb, 1976; Harandi, Taghinasab, \& Nayen, 2017). More clearly explained by Lee (2019), which said that social support and its influence on health through two theoretical frameworks, namely the buffering theory, is essentially that support will counteract the negative effects of stressors, and the direct effect model believes that the usefulness of support social is when there is no stress. According to Kang, Park, and Hernandez (2018) perceptions of social support are subjective judgments of individuals who obtain social support in affective and attitudinal forms, such as empathy and instrumental support such as direct assistance. The role of perceptions of social support is important because before individuals can receive social support, they must be able to perceive social support in advance to help deal with stressful situations and becoming less stressful (Srivastava \& Angelo, 2009; Abimbola and Ugbede, 2018).

Based on the results of the research by Mirghafourvandm, Baheiraei, Nedjat, Mohammadi, Charandabi, and Majdzadeh (2014), the perception of social support is a predictor of healthpromoting behavior. This is because perceptions of social support can be an individual protective factor as a result of stressful life experiences, as well as helping individuals to achieve physical and emotional needs that are assessed as part of health-promoting behavior (Bomar, 2004). The results of this study were confirmed by Arash et al (2015) which proved that the perception of social support was significantly correlated with health-promoting behavior. Social support refers to the quality of relationships emotionally, such as feeling loved, cared for, and listened to. Social support is proven 
to have an impact on physical and mental health, by reducing the impact of stress or raising meaning and purpose in life (Cohen, 2004; Uchino, 2004), thereby reducing psychological distress. In addition, social support has been shown to reduce blood pressure, heart rate and stress hormones that are beneficial for health (Uchino, 2006). According to Thoits (2006) social support strengthens the presence of personal control, that is, individual beliefs can regulate the impact of all actions or decisions taken on life, and personal control is useful to encourage individuals to engage in healthy behavior.

Health-promoting behavior was also shown to reduce psychological distress. The results of Harding's (2012) study show that 06659 health-promoting behavior 06669 has a significant negative relationship with psychological distress. The study was confirmed by the results of Kim et al. (2015) which showed that the health-promoting behavior had a significant negative relationship with psychological distress. This can be explained by the mechanism that health-promoting behavior can affect individual perceptions of quality of life (Kim et al., 2015), and can maintain functioning and improve individual life satisfaction (Chuang, Wu, Wang, \& Pan, 20I7), so can reduce psychological distress.

Based on literature studies conducted by researchers, there are no studies that directly examine the relationship between perceptions of social support, health-promoting behavior, and psychological distress. There are several studies that examine health-promoting behavior, but not exactly its relationship with perceptions of social support and psychological distress (Cho et al., 20I4; Jackson et al., 2017). Thus, the researcher proposes the research problem formulation, is health-promoting behavior a mediator in relation to the perception of social support with psychological distress? Researchers suspect that the perception of social support can affect health-promoting behavior by helping individuals achieve physical and emotional needs, and that the health-promoting behavior can reduce psychological distress because it can affect individuals to their quality of life. In conclusion, our research hypothesis is health-promoting behavior as a mediator of the relationship between perceptions of social support and psychological distress. 


\section{Method}

\section{Subjects}

This study is a non-experimental study, and cross-sectional design, with a total of 314 participants aged 18 to 29 years, with a minimum provision of receiving one government assistance specifically for people with disadvantaged economic status, such as $\mathrm{KJP}, \mathrm{PKH}$, and so on. The research data collection was carried out in offline or by visiting research participants directly for five days in DKI Jakarta, namely to Kayumanis in East Jakarta, South Manggarai in South Jakarta, Kalianyar in West Jakarta, Kalibaru in North Jakarta, and Petamburan in Central Jakarta. Determination of this area is based on kelurahan which is classified as densely populated and slum based on BPS and kelurahan data. Before the data collection, participants were asked for their informed consent.

\section{Measurement}

This study uses three measuring instruments to measure the three research variables, namely HSCL25 ( Hopkins Symptom Checklist -25) which has been adapted into Indonesian with an alpha coefficient of 0.927 , based on reliability tests showing correlation coefficients ranging from 0.322 up to 0.779 . Thus the HSCL-25 proved to be valid and reliable in measuring psychological distress. $\mathrm{HSCL}$ meant to measure psychological distress that consists of depression and anxiety symptoms. These are the examples of HSCL-25 items: "feeling panic", "crying easily", "feeling hopeless". Healthpromoting behavior was measured using Health Promoting Lifestyle Profile II (HPLP II) developed by Walker, Sechrist, and Pender (1995) and has been adapted into Indonesian by Atikah (2017). These are the examples of HPLP II items: "get enough sleep”, "follow a planned exercise programme”, "look forward to the future". Perception of social support was measured using Social Provisions Scale with a reliability score of 0.915 (Cutrona \& Russel, 1987). These are three examples of SPS items: "no one needs me to care for them", "there are people who admire my talents and abilities", "there is no one who shares my interests and concerns".

\section{Data Analysis}

This study used descriptive analysis techniques to see the description of participants' demographic data. Then the researcher also used the PROCESS analysis technique from Hayes (2013) with simple mediation model, model 4 to see health-promoting behavior as a mediator of the relationship between perceptions of social support and psychological distress. The research data was processed with IBM SPSS version 25. 


\section{Results}

The results showed that the majority of participants aged 19 years with a percentage of $13.4 \%$ with fairly good data spread, representing ages 21 years to 29 years $(S D=3.4)$. Most of the participants were female, namely $79.3 \%$ of the total participants. Then, the last educated participants were SMA / SMK / Package C with a percentage of $54.5 \%$. Then from the domicile data, it is known that most of the participants lived in East Jakarta, which were 150 (47.8\%), with marital status of marriage of $56.7 \%$. See table I below.

Table I

Characteristics of Participants ( $N=3 / 4)$

Characteristics of Participants

$N \quad$ Mean SD $\%$

\begin{tabular}{|c|c|c|c|c|}
\hline Age & 314 & & 3.4 & \\
\hline 18 years old & 24 & & & 7.6 \\
\hline 19 years old & 42 & & & 13.4 \\
\hline 20 years old & 20 & & & 6.4 \\
\hline 21 years old & 24 & & & 7.6 \\
\hline 22 years old & 32 & & & 10.2 \\
\hline Characteristics of Participants & $\mathrm{N}$ & Mean & SD & $\%$ \\
\hline Age & 314 & & 3.4 & \\
\hline 25 years old & 28 & & & 8.9 \\
\hline 26 years old & 22 & & & 7.0 \\
\hline 27 years old & 25 & & & 8.0 \\
\hline 28 years old & 25 & & & 8.0 \\
\hline 29 years old & 20 & & & 6.4 \\
\hline \multicolumn{5}{|l|}{ Gender } \\
\hline Male & 65 & & & 20.7 \\
\hline Female & 249 & & & 79.3 \\
\hline
\end{tabular}




\section{Educational History}

SD / Package A

30

Middle School / Package B 78

SMA / SMK / Package C

|7|

Diploma

Bachelor's degree

13

20

Above Bachelor's Degree
54.5

9.6

24.8

4. 1

6.4

0.3

Domicile

West Jakarta

East Jakarta

Central Jakarta

South Jakarta

Marital Status

Not married

Married

Divorce (Alive)

Divorce (Dead)
98

150

16

50

132

178

3

I
31.2

47.8

5. I

15.9

42.0

56.7

I.0

0.3

The results of testing the main hypothesis of the study are that there is a significant influence on perceptions of social support with psychological distress $(B=-.0220, p<0.01$ ). These results prove that the higher the perception of social support, the lower the psychological distress experienced by individuals. Furthermore, perceptions of social support were also significantly related to healthpromoting behavior $(\beta=.0272, p<0.01)$, the higher the perception of social support, the higher health -promoting behavior. 
Table 2

Results of Analysis with Simple Mediation Model

\section{Consequent}

\begin{tabular}{|c|c|c|c|c|c|c|c|c|c|c|}
\hline \multirow[t]{2}{*}{ Antecedents } & \multicolumn{5}{|c|}{ Health-promoting Behavior } & \multicolumn{5}{|c|}{ Psychological Distress } \\
\hline & Koef. & SE & $p$ & $\mathrm{LLCl}$ & ULCI & Koef. & SE & $p$ & $\mathrm{LLCl}$ & ULCI \\
\hline $\begin{array}{l}\text { Perception } \\
\text { of social } \\
\text { support }\end{array}$ & .027 & .0062 & 0.000 & -.0394 & -0150 & -.022 & .0076 & .0042 & -.0370 & -.0070 \\
\hline $\begin{array}{l}\text { Health- } \\
\text { promoting } \\
\text { behavior }\end{array}$ & - & - & - & - & - & -.141 & .0676 & .0381 & -.2737 & -.0078 \\
\hline Constant & 4.04 & .3483 & 0.000 & 3.358 & 4.7295 & 3.200 & .4975 & 0.0000 & 2.221 & 4.179 \\
\hline & \multicolumn{5}{|c|}{$\mathrm{R}^{2}=0.57$} & \multicolumn{5}{|c|}{$R^{2}=0.32$} \\
\hline & \multicolumn{5}{|c|}{$F(I, 3 \mid 2)=19.18, p<.01$} & \multicolumn{5}{|c|}{$F(2,3 I I)=5.188, p<.01$} \\
\hline
\end{tabular}

The results also prove that there is a significant negative relationship between with health distress with psychological distress $(\beta=-1408, p<0.01)$. Based on the analysis of effect size, the score $R^{2}=$ 0.57 , it can be interpreted as $57 \%$ variant of health-promoting behavior is influenced by perceptions of social support and score $\mathrm{R}^{2}=0.32$ means that $32 \%$ of the variant from psychological distress is influenced by perceptions of social support and health-promoting behavior.

The results of statistical tests show there are direct effect on perceptions of social support $(\beta=-.022$, $P<0.0 I)$. Direct effect shows that there is a relationship between the perception of social support and direct psychological distress. In addition, there are also significant indirect effect $(\beta=.029, p<$ 0.01 ), which means that the relationship between perceptions of social support and psychological distress is mediated by health-promoting behavior. Thus, it can be concluded that the healthpromoting behavior mediates the relationship partially. Perceptions of social support can directly influence psychological distress or through health-promoting behavior first. 


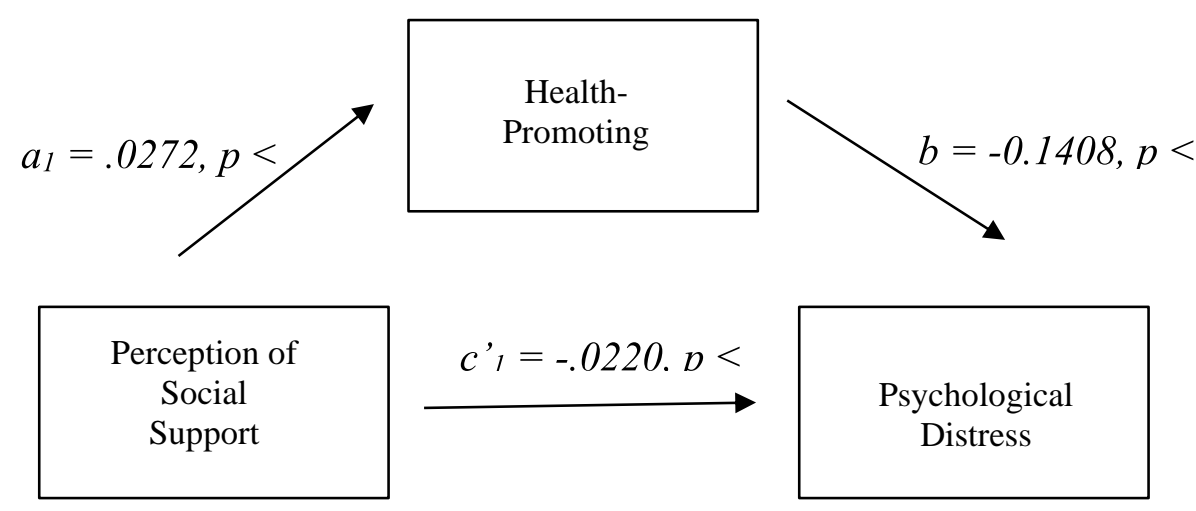

Figure 4.I Simple Mediation Analysis Result

\section{Discussion}

The development period of young adults is prone to mental health problems (Bonnie, Stroud, \& Breiner, 2015). This is also confirmed by the results of research that poor young adults in DKI Jakarta experience psychological distress. Psychological distress is important to get further attention by looking for a variety of factors that can reduce psychological distress, such as health-promoting behavior and perceptions of social support. Health-promoting behavior mediates the relationship between perceptions of social support and psychological distress. The mechanism of the relationship can be explained by individuals who perceive social support will feel loved, listened to, and cared for, then have an impact on physical and mental health by raising the meaning of life and life goals (Cohen, 2004; Uchino, 2004), which encourages individuals to get involved in healthy behavior, thereby reducing psychological distress. The results of these studies are in accordance with Umberson, Crosnoe, and Reczek (2010) who explain that social support influences healthy behavior. Good social relations have an effect on healthy behavior because it can give rise to the attitude of controlling healthy behavior (Umberson et al., 2010). Social support can have an impact on psychological distress by activating immune functions involved in responding to stress (Uchino, 2004). The role of perceptions of social support reduces physiological responses such as cardiac activity in anticipation of the presence of stressors (Glynn, Christenfeld, \& Gerin, 1999).

According to the developmental theory of Erikson (Feist \& Feist, 2013) individuals at a young adult age have a developmental task of building close relationships with others. If the task of development 
is not fulfilled, the individual will feel lonely and isolated. The results of the study by Cheung and Sim (2016) prove that the population of adolescents in Singapore perceives more social support from family than friends or peer groups. Based on the results of the study, the researchers did not see various sources of social support from families, peer groups, etc. with psychological distress, so researchers suggested further research to see the types of sources of social support that were more influential on psychological distress, especially in young adults. Health promoting behavior on HPLP II measuring instruments has dimensions of spiritual growth, interpersonal relationships, nutrition, physical activity, health responsibility, and stress management. According to Hosseini, Ashktorab, Taghdisi, Khodayari, Yarmohammadyani, and Salimi (2016) the dimensions of interpersonal relations are wrong one of the six dimensions health-promoting behavior which can describe health-promoting behavior in nursing students of young adults. The results of the study became the lighters of further research to consider or further study six dimensions in the HPLP-II measuring instrument.

Considering the results of the study, perceptions of social support and health-promoting behaviors are becoming strong predictors of reducing psychological distress. The study recommended various parties such as government, health services, schools, and other professionals to use the effectiveness of perceptions of social support and health. Public policy should pay more attention to behavioral change in addressing distress found in communities. The study also recommends health-promoting behavior as an alternative intervention program for mental health problems, especially anxiety and depression as components of psychological distress. One of the possible ways is to make the healthpromoting behavior as the target intervention both psychologically and embedded in other fields such as medical therapy.

\section{Conclusion}

The results of this study indicate that health-promoting behavior mediates the relationship between perceptions of social support and partial psychological distress. Individuals who perceive themselves to get social support will feel cared for and loved, so that they will make individuals more meaningful and have life goals, thus motivating them to get involved in healthy behavior, and reduce psychological distress. 


\section{References}

Bednar, D.E. \& Fisher, T.D. (2003). Peer referencing in adolescent decision making as a function of perceived parenting style. Adolescence, 38(I52), 607-2I.

Baumrind, D. (197I). Current patterns of parental authority. Developmental Psychology Monographs, 4, I0I-103.

Duvall, E. M. \& Miller, B. C. (1985). Marriage and family development (6th Ed.). New York: Harper \& Row Publisher.

Grolnick, W. S. (2003). The psychology of parental control: How well-meant parenting backfires. New York, NY: Taylor and Francis Group.

Heinonen K, Räikkönen K, Matthews KA, et al. Socioeconomic status in childhood and adulthood: Associations with dispositional optimism and pessimism over a 21 -year follow-up. Journal of Personality, 74, IIII-II26. [PubMed: 16787430]

Lund, C., Stansfeld, S., \& De Silva, M. (20I4). Social determinants of mental health. In V. Patel, H. Minas, A. Cohen, \& M. J. Prince (Eds.). Global mental health: Principles and practice. New York, NY: Oxford University Press

Meevissen, Y. M., Peters, M. L., \& Alberts, H. J. (20I I). Become more optimistic by imagining a best possible self: Effects of a two-week intervention. Journal of Behavior Therapy and Experimental Psychiatry, 42(3), 37I-378.

Mirowsky, J \& Ross, C.E. (2003). Social causes of psychological distress. New York: Aldine de Gruyter.

Petersen, I., Barry, M., Lund, C., \& Bhana, A. (20I4). Mental health promotion and the prevention of mental disorders. In V. Patel, H. Minas, A. Cohen, \& M.J. Prince (Eds.). Global mental health: Principles and practice. New York, NY: Oxford University Press.

Peraturan Daerah (Perda) Nomor 15 tahun 2013 tentang Penyelenggaraan Kota Layak Anak (KLA).

Pinquart, M. \& Kauser, R. (2017). Do the associations of parenting styles with behavior problems and academic achievement vary by culture? Results from a meta-analysis. Culture Divers Ethnic Minor Psychol. doi: 10.1037/cdp0000 I49. [Epub ahead of print]

Scheier, M. F. \& Carver, C. S. (1985). Optimism, coping, and health: Assessment and implications of generalized outcome expectancies. Health Psychology,4(3), 219-247.

Scheier, M. F. \& Carver, C. S. (1993) On the power of positive thinking: The benefits of being optimistic. Current Directions in Psychological Science, 2(I), 26-30. 
Scheier, M. F., Carver, C. S., \& Bridges, M. W. (1994). Distinguishing optimism from neuroticism (and trait anxiety, self-mastery, and self-esteem): A reevaluation of the life orientation test. Journal of Personality and Social Psychology, 67(6), 10631078.

Scheier, M. F., Carver, C. S., \& Segerstorm, S. C. (2010). Optimism. Clinical Psychology Review, 30, 879 889.

Tim Nasional Percepatan Penanggulangan Kemiskinan (20I5). Sebaran | Data terpadu PPFM Jawa Barat kota Depok. Diakses pada 21 Februari 2019 di http://bdt.tnp2k.go.id/sebaran/Silalahi, Karlinawati \& Eko A Meinarno (Ed). (2010). Keluarga Indonesia: Aspek dan dinamikazaman. Jakarta: Raja Grafindo Persada.

Thalib, S. B. (2019). Psikologi pendidikan berbasis analisis empiris aplikatif. Jakarta: Kencana

Undang-Undang Republik Indonesia Nomor 52. (2009). Perkembangan kependudukan danpembangunan keluarga dengan Rahmat Tuhan yang Maha Esa Presiden Republik

Indonesia. Diakses pada 19 September 2019 dihttps://jdih.kemenpppa.go.id/peraturan/uu\%20no\%.pdf. 